\title{
Physiologic Antagonist
}

National Cancer Institute

\section{Source}

National Cancer Institute. Physiologic Antagonist. NCI Thesaurus. Code C156615.

A substance that binds to and activates a receptor and produces a biological effect which inhibits or negates the biological response produced by an agonist at a different receptor. 